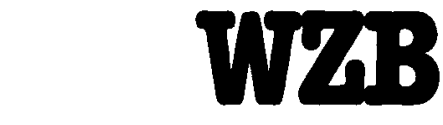

WISSENSCHAFTSZENTRUM BERLIN

FÜR SOZIALFORSCHUNG

SOCIAL SCIENCE RESEARCH

CENTER BERLIN

\author{
Paolo Buccirossi * \\ Lorenzo Ciari ** \\ Tomaso Duso *** \\ Giancarlo Spagnolo **** \\ Cristiana Vitale *
}

\title{
Deterrence in Competition Law
}

\author{
* LEAR \\ ** Lear and EUI \\ *** Humboldt University Berlin and WZB

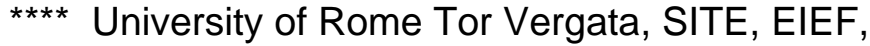 \\ CEPR
}

SP || 2009 - 14

October 2009

ISSN Nr. $0722-6748$

Research Area

Markets and Politics

Research Group

Competition and Innovation
Schwerpunkt II

Märkte und Politik

Forschungsgruppe

Wettbewerb und Innovation 
Zitierweise/Citation:

Paolo Buccirossi, Lorenzo Ciari, Tomaso Duso, Giancarlo Spagnolo, Cristiana Vitale, Deterrence in Competition Law, Discussion Paper SP II 2009 - 14, Wissenschaftszentrum Berlin, 2009.

Wissenschaftszentrum Berlin für Sozialforschung gGmbH, Reichpietschufer 50, 10785 Berlin, Germany, Tel. (030) 25491 - 0 Internet: www.wzb.eu 
ABSTRACT

\section{Deterrence in Competition Law *}

by Paolo Buccirossi, Lorenzo Ciari, Tomaso Duso, Giancarlo Spagnolo, Cristiana Vitale

This paper provides a comprehensive discussion of the deterrence properties of a competition policy regime. On the basis of the economic theory of law enforcement we identify several factors that are likely to affect its degree of deterrence: 1) sanctions and damages; 2) financial and human resources; 3) powers during the investigation; 4) quality of the law; 5) independence and 6) separation of power. We then discuss how to measure deterrence. We review the literature that uses surveys to solicit direct information on changes in the behavior of firms due to the threats posed by the enforcement of antitrust rules, and the literature based on the analysis of hard data. We finally argue that the most challenging task, both theoretically and empirically, is how to distinguish between "good" deterrence and "bad" deterrence.

Keywords: Competition Policy, Law Enforcement, Deterrence

JEL Classification: K21, K42, L4

This paper is based on a research project we undertook for the Directorate General for Economic and Financial Affairs of the European Commission, with the support of the Directorate General for Competition. We would like to thank Fabienne Ilzkovitz, Roderick Meiklejohn, Adriaan Dierx and Francesco Montaruli for their comments on previous drafts of this paper and Gianmarco Calanchi and Paolo Colonna for their excellent research assistance. Tomaso Duso gratefully acknowledges financial support from the Deutsche Forschungsgemeinschaft through SFB/TR 15. 


\section{ZUSAMMENFASSUNG}

\section{Abschreckung im Wettbewerbsrecht}

Dieser Beitrag bietet eine umfassende Diskussion über die Abschreckungseigenschaften eines wettbewerbspolitischen Systems. Auf der Grundlage der ökonomischen Theorie der Rechtsdurchsetzung werden mehrere Faktoren identifizier, welche den Abschreckungsgrad des Systems am ehesten beeinflussen können. Diese sind: 1) Sanktionen und Schadensersatzforderungen, 2) finanzielle Ressourcen und Personal der Wettbewerbsbehörde, 3) die Befugnisse der wettbewerbspolitischen Autorität im Rahmen der Untersuchung, 4) die Qualität des Rechtsrahmens, 5) die Unabhängigkeit der Behörde und 6) die Gewaltenteilung. Anschließend wird diskutiert, wie man den Abschreckungsgrad eines wettbewerbspolitischen Systems empirisch messen kann. Zuerst wird die Literatur besprochen, die auf Befragungen beruht. Die Befragungen sollten Aufschluss darüber geben, wie sich das Unternehmensverhalten angesichts der Durchsetzung von wettbewerbspolitischen Maßnahmen ändert. Dem gegenüber wird die Literatur dargestellt, die "harte" Daten nutzt. Schließlich wird argumentiert, dass die anspruchsvollste Aufgabe sowohl theoretisch als auch empirisch darin bestehen wird, zwischen "guter" und "schlechter" Abschreckung durch Wettbewerbspolitik zu unterscheiden. 


\title{
Deterrence in Competition Law
}

\author{
Paolo Buccirossi ${ }^{\dagger}$, Lorenzo Ciari ${ }^{\ddagger}$, Tomaso Duso ${ }^{\S}$, \\ Giancarlo Spagnolo ${ }^{* *} \uparrow$, and Cristiana Vitale ${ }^{\dagger \dagger}$
}

\begin{abstract}
This paper provides a comprehensive discussion of the deterrence properties of a competition policy regime. On the basis of the economic theory of law enforcement we identify several factors that are likely to affect its degree of deterrence: 1) sanctions and damages; 2) financial and human resources; 3) powers during the investigation; 4) quality of the law; 5) independence; and 6) separation of power. We then discuss how to measure deterrence. We review the literature that use surveys to solicit direct information on changes in the behavior of firms due to the threats posed by the enforcement of antitrust rules, and the literature based on the analysis of hard data. We finally argue that the most challenging task, both theoretically and empirically, is how to distinguish between "good" deterrence and "bad" deterrence.
\end{abstract}

Keywords: Competition Policy, Law Enforcement, Deterrence

JEL classification: K21, K42, L4

\footnotetext{
* This paper is based on a research project we undertook for the Directorate General for Economic and Financial Affairs of the European Commission, with the support of the Directorate General for Competition. We would like to thank Fabienne Ilzkovitz, Roderick Meiklejohn, Adriaan Dierx and Francesco Montaruli for their comments on previous drafts of this paper and Gianmarco Calanchi and Paolo Colonna for their excellent research assistance. Tomaso Duso gratefully acknowledges financial support from the Deutsche Forschungsgemeinschaft through SFB/TR 15.

† Corresponding author Lear, via del Banco S. Spirito 42, 00186 Rome, Italy; email: paolo.buccirossi@learlab.com

${ }^{\ddagger}$ Lear and EUI

${ }^{\S}$ Humboldt University Berlin and WZB

** University of Rome Tor Vergata, SITE, EIEF, CEPR.

†† Lear
} 


\section{Introduction}

Deterrence is a central theme in the theory and practice of law enforcement, and the enforcement of competition law is no exception. Laws are enacted with the aim to influence people's behavior so that socially undesirable conduct is not undertaken. A law enforcement system that "taxes” agents for undertaking unlawful behavior, but is not able prevent them would be a waste of resources from an economic point of view. Indeed, the enforcement of law is costly. It requires resources to monitor agents' behavior, to detect infringements, to prove violations, and to inflict punishments. These resources might best be devoted to other aims. Moreover, the sanction imposed on apprehended wrongdoers is, at best, a mere transfer that does not improve social welfare. If these costly activities and transfers do not modify the rate at which agents undertake harmful actions then society does not benefit from them. Therefore, enforcement without any deterrence entails social costs and no economic benefits.

These statements are not new in law, economics and political science. They date back to the insights of 18th century thinkers like Montesquieu, Beccaria, and Bentham. More recently, several authors have analyzed the issue of how competition law enforcement can deter anticompetitive behaviors. Previous analyses, however, focus mostly on sanctions and discuss the sanction policy that ensures optimal deterrence. This literature deals with the use of criminal sanctions ${ }^{1}$, the optimal level of fines, ${ }^{2}$ the

${ }^{1}$ See W.M. Landes, Optimal Sanctions for Antitrust Violations, 50 The University of Chicago Law Review 652 (1983); G.J. Werden, M.J. Simon, Why Price Fixers Should Go to Prison, 32 The Antitrust Bulletin 917 (1987); J.C. Gallo, K.G. Dau Schmidt, J.L. Craycraft, C. J. Parker, Criminal Penalties Under the Sherman Act: A Study of Law and Economics, 16 Research in Law and Economics 25 (1994); B. Kobayashi, Antitrust, Agency and Amnesty: An Economic Analysis of the Criminal Enforcement of the Antitrust Laws Against Corporations, George Mason University School of Law, Working Paper No. 02-04 (1994); G. Spagnolo, Cartels Criminalization and their Internal Organization, in Cseres, K.J., Schinkel, M.P., Vogelaar, F.O.W., (Eds.), Remedies and Sanctions in Competition Policy: Economic and Legal Implications of the Tendency to Criminalize Antitrust Enforcement in the EU Member States, Edwar Elgar, London (2006); W. Wils, Is Criminalization of EU Competition Law the Answer?, in Cseres, K.J., Schinkel, M.P., Vogelaar, F.O.W., (Eds.), Remedies and Sanctions in Competition Policy: Economic and Legal Implications of the Tendency to Criminalize Antitrust Enforcement in the EU Member States, Edwar Elgar, London (2006).

${ }^{2}$ See P. Buccirossi and G. Spagnolo, Optimal Fines in the Era of Whistleblowers: Should Price Fixers Still Go To Prison?, in V. Goshal and J. Stennek (Eds.), The Political Economy of Antitrust, Elsevier, North Holland (2007);.J.M. Connor, Optimal Deterrence and Private Antitrust Enforcement, Manuscript, Purdue University (2005); C. Craycraft, J.L Craycraft, J. Gallo, Antitrust Sanctions and Firm Ability to Pay, 12 Review of Industrial Organization 171 (1997); D. Geradin, D. Henry, The EC Fining Policy for Violations of Competition Law: An empirical Review of the Commission Decisional Practice and the Community Courts' Judgments, in Cseres, K.J., Schinkel, M.P., Vogelaar, F.O.W., 
contribution of private litigation and damage suits to the achievement of the public goals pursued by competition law ${ }^{3}$ and the implications for deterrence of leniency policies. ${ }^{4}$ Yet, these analyses do not provide a full picture of the role of deterrence, because competition policy is much more than a sanction policy. Hence, we believe that it is important to understand which features of a competition policy regime have a significant and positive impact on its ability to deter anticompetitive behavior.

First of all, we must clarify what we understand as competition policy. A competition policy regime is defined by a number of institutional and enforcement features. The former relate to the status of the enforcement agencies, the role of courts in the adjudication of competition law cases, the procedures that must be followed to establish an infringement, the investigative powers held by the enforcer and the substantive rules. The latter, the enforcement features, concern the quantity and quality of the financial and human resources that are devoted to the implementation of the policy, the way these resources are used to investigate potential infringements and the actual sanctions levied on apprehended wrongdoers.

This paper provides some reflections on how the institutional and enforcement features of a competition policy regime affect its deterrence properties. Section 2 recalls the basic economic theory of optimal deterrence and its determinants, distinguishing between general deterrence and specific deterrence and identifying the cases in which the enforcement activity generates over-deterrence. Section 3 examines how the main findings from economic theory apply to the realm of competition policy. It argues that deterrence is affected by three main factors: (a) the level of the loss incurred by those who infringe the law and are detected and convicted; (b) the (perceived) probability of being detected and convicted; and (c) the (perceived) probability of being wrongly convicted or acquitted. The same section,

(Eds.), Remedies and Sanctions in Competition Policy: Economic and Legal Implications of the Tendency to Criminalize Antitrust Enforcement in the EU Member States, Edwar Elgar, London (2006); W. Wils, Optimal Antitrust Fines: Theory and Practice, 29 World Competition 2 (2006).

${ }^{3}$ See W. Wils, Should Private Antitrust Enforcement be Encouraged in Europe?, 26 World Competition 473 (2003).

${ }^{4}$ See M. Motta, M. Polo, Leniency Programs and Cartel Prosecution. 21 International Journal of Industrial Organization 347 (2003); C. Aubert, W. E. Kovacic, P. Rey, The Impact of Leniency and Whistleblowers Programs on Cartels 29(6) International Journal of Industrial Organization 1241 (2006);; G. Spagnolo, Divide et Impera: Optimal Leniency Programs, CEPR Discussion Paper No. 4840 (2004); G. Spagnolo, Leniency and Whistleblowers in Antitrust, in P. Buccirossi (Ed.), Handbook of Antitrust Economics, MIT Press, Cambridge, MA (2008); J. Harrington, Optimal Corporate Leniency Programs, 56(2) Journal of Industrial Economics 215 (2008). 
relates the institutional and enforcement features of a competition policy regime to these three factors. Section 4 deals with the problem of how to measure deterrence. It describes the difficulties of measuring deterrence in cases in which the infringements are not observable, as it is for most competition law infringements. Section 5 presents our main conclusions.

\section{The notion of deterrence}

\subsection{General and specific deterrence}

Deterrence of unlawful behavior may take different forms. ${ }^{5}$ The most relevant ones are: general deterrence and specific deterrence.

General deterrence, also referred to as ex-ante deterrence, consists of preventing agents from undertaking illegal behaviors by threatening violators with sufficiently heavy sanctions. Its optimal level, from an economic point of view, is achieved when only those conducts that cause harm to society, which is larger than the net gain that accrues to the wrongdoers, are prevented. If the enforcement costs are zero and there is perfect and symmetric information, this level of deterrence can be obtained by setting the actual sanction, $S$, and the perceived probability of being detected and convicted, $a$, at a level such that the expected sanction, $S^{*} a$, equals the social harm, $H:$

$$
S^{*} a=H
$$

This simple rule, also known as Becker's rule ${ }^{6}$, implies that, for all those conducts that are socially inefficient - in that the wrongdoer's gain $(G)$ is lower than the social harm - the expected sanction is greater than the gain (i.e. $S^{*} a>G$ ). Therefore, the

\footnotetext{
${ }^{5}$ For an in-depth criminological discussion of the different forms of deterrence for various types of unlawful behaviors see T. J. Bernard, J. Snipes and G. B. Vold., Theoretical Criminology, Oxford University Press (2001). For a review of the basic theory of deterrence see S. Shavell, Economic Analysis of Public Law Enforcement and Criminal Law, Harvard Law and Economics Discussion Paper No. 405 (2003). For an extensive discussion of deterrence in the context of competition policy see P. Buccirossi and G. Spagnolo, supra note 2.

${ }^{6}$ The design of the optimal sanction is one of the key results of Becker's seminal paper, G. Becker Crime and Punishment an economic approach, , 76(2) Journal of Political Economy 169 (1968).
} 
potential wrongdoer will not undertake it, as her expected payoff is negative, i.e. she is deterred from violating the law. On the contrary, all the socially efficient conducts, in which the wrongdoer's gain is larger than the social harm, will be undertaken, as the expected sanction is lower than the gain (i.e. $S^{*} a \leq G$ ). In a nutshell, Becker's rule induces the offenders to internalize the social costs of their actions, and in a world with no enforcement costs and perfect information it ensures ex-ante deterrence of all socially inefficient acts.

Another important form of deterrence is specific deterrence, sometimes called desistance, which takes place ex post, i.e. after an unlawful behavior has taken place and has been discovered by the law enforcement agency. This form of deterrence works through a change in the information held by the agents. For example, if agents do not have perfect knowledge of the probability of being detected and convicted, i.e. $a$ in (1.1), being caught and punished provides them with new information to update their expectations ${ }^{7}$. The very experience of being sanctioned may also have the effect of deterring further wrongdoing through the so-called punishment induced deterrence, a behavioral increase in the salience of the expected sanction ${ }^{8}$.

General deterrence is typically the primary objective of law enforcement, as it can be achieved for a very large number of potential infringements without the need for these to be detected by law enforcers. This allows a saving of: the costs of the budgets of the courts and agencies involved in the investigation and prosecution of the alleged crimes, the cost of the distortionary taxation required to finance these budgets, the private costs of litigation, and the social and private costs of imposing sanctions on

\footnotetext{
${ }^{7}$ Specific deterrence can also operate through a change in the costs and/or benefits of committing an additional crime, when the legal system contemplates increased sanctions for repeat offenders, incapacitation (by imprisonment or disqualification), and special monitoring of convicted wrongdoers. G. J. Stigler, The optimum enforcement of laws, 78 Journal of Political Economy, 526 (1970); A. Rubinstein An optimal conviction policy for offenses that may have been committed by accident, in: S. J.Brams, A. Schotter and G. Schwodiauer, eds., Applied Game Theory, Physica-Verlag, Wurzburg, 406 (1979); A. M. Polinsky, D. L. Rubinfeld A model of optimal fines for repeat offenders, 46 Journal of Public Economics 291 (1991); C. Y. C. Chu, S. Hu, T. Huang Punishing repeat offenders more severely, 20 International Review of Law and Economics 127 (2000); W. Emons, Escalating penalties for repeat offenders, 27 International Review of Law and Economics 170 (2007) contain convincing discussions of the reasons why sanctions should generally be increasing for repeat offenders.

${ }^{8}$ This punishment-induced deterrence effect has been quantified recently in a field experiment on videotape rental by , P. Fishman, D. G. Pope, Punishmen-induced deterrence: Evidence from the video rental Market, Working Paper, University of California, Berkeley (2006) and in a laboratory experiment on competition policy by M.Bigoni, C. Le Coq, S. Fridolfsson, and G. Spagnolo, Risk Aversion, Prospect Theory, and Strategic Risk in Law Enforcement: Evidence From an Antitrust Experiment, manuscript, SITE Stockholm School of Economics, University of Tor Vergata, IMT Lucca, and the Stockholm
} 
the convicted parties. In addition, general deterrence avoids all the damages that each illegal action would have caused had it not been prevented. Hence, the most important part of the activity of a law enforcement agency, whose aim is to maximize social welfare, should consist of deterring violations, rather than identifying and punishing wrongdoers. In an ideal world, this activity should be sufficient to control misconducts, making desistance unnecessary.

\subsection{Over-deterrence}

The optimal level of ex-ante deterrence should not only ensure the prevention of all illegal and socially inefficient actions, but it should also avoid refraining agents from undertaking actions that improve social welfare. In other words, ex-ante deterrence, to be at its optimal level, should never become over-deterrence. Over-deterrence takes place when the expected sanction is too high, thus stopping agents from undertaking actions whose gain is actually higher than the harm they cause to society (i.e. $a^{*} S>$ $H$ ). Over-deterrence can occur either when the sanction has been set at too high a level $^{9}$ or when the enforcement effort, which determines the level of the probability of being caught and convicted, is excessive ${ }^{10}$.

\subsection{Deterrence in a more complex world}

The application of Becker's rule guarantees the optimal level of ex-ante deterrence, but only in a world of perfect information and with no enforcement costs. Over the years this rule has been refined by a series of contributions that have considered what happens if one relaxes these conditions. For example, in their encompassing survey of the economic literature on the enforcement of law, Polinsky and Shavell ${ }^{11}$ suggest

\footnotetext{
${ }^{9}$ In the case of anticompetitive behaviors, this can happen as the loss an agent incurs is actually given by the sum of "sanctions" imposed by different bodies which do not coordinate their decisions (e.g. the fines imposed by the competition authority and the private damages awarded by the court)

${ }^{10}$ With regard to the EU, over-deterrence does not seem to be a problem since legal actions for private damages are still rare and the fines imposed on misbehaving firms appear to be too low to display any substantial deterrence effect, see D. Waelbroeck, D. Slater and G. Even-Shoshan, Study on the conditions of claims for damages in case of infringement of EC competition rules, Ashurst (2004); C. Veljanovski, Cartel Fines in Europe - Law, Practice and Deterrence, 29 World Competition (2007) and M.P. Schinkel Effective Cartel Enforcement in Europe, 30(4) World Competition, 539 (2007).

${ }^{11}$ See A. M. Polinsky and S. Shavell, The Economic Theory of Public Enforcement of Law, Stanford Law School, John M. Olin Program in Law and Economics, Working Paper No. 159 (2000).
} 
that, since the investigation of alleged crimes and the imposition of sanctions has a cost, sanctions should be set so as not to deter all inefficient conducts. They should be set only up to the point at which the harm caused to society by these conducts is larger than the gain accrued to the wrongdoer plus the value of the resources saved by not enforcing the law.

Even if one assumes that information is difficult and costly to obtain and, thus, that the law enforcement agency may commit mistakes when investigating potential crimes, the probability of these errors should be considered when setting the optimal level of the sanction. Indeed the incidence of unlawful behaviors increases with the enforcement agency's errors for two reasons ${ }^{12}$. Firstly, and most obviously, if agents are aware that the agency may acquit wrongdoers (i.e. it commits a type I error), the perceived and actual probability of being punished when behaving unlawfully goes down, leading to lower expected sanctions. Secondly, if agents risk being unjustly sanctioned despite having complied with the law (i.e. if type II errors happen), the relative gain from illegal actions increases relative to legal ones, reducing the deterrence effects of sanctions. Hence, if the enforcement agency makes mistakes, but not too frequently, optimal sanctions should be higher than the Beckerian level ${ }^{13}$.

Errors can also be committed by the agents when trying to forecast the effects of their actions, and thus the reaction of the enforcement agency. This is especially true in the case of competition law where, if a given behavior has complex economic effects, assessing whether it is actually anticompetitive may be difficult both for the enforcement agency and for the firms undertaking it. The complexity of the evaluation and the risk of the agency making a mistake imply that a firm may be deterred from undertaking a perfectly legal competitive behavior under the mistaken assumption that it is illegal, in which case general deterrence generates a reduction in social welfare. Similarly, a firm may undertake an anticompetitive behavior because it

\footnotetext{
${ }^{12}$ See S. Shavell, Eonomic Analysis of Public Law Enforcement and Criminal Law, Harvard Law and Economics Discussion Paper No. 405. (2003); M. Polinsky and S. Shavell, supra note 11; P. Buccirossi, L. Ciari, T. Duso, S.O. Fridolfssn, G. Spagnolo and C. Vitale, Ex-post Review of Merger Control Decisions, prepared for the DG COMP of the European Commission.

${ }^{13}$ If $\varepsilon_{I}$ and $\varepsilon_{I I}$ respectively indicate the probability that the enforcement agency incurs in type I and type II errors, the optimal sanction should then satisfy the following adjusted Becker's rule: $S^{*} a\left(1-\varepsilon_{I}-\varepsilon_{I I}\right)$ $=H$. Clearly, if the enforcement agency makes too many mistakes, it is instead optimal not to enforce the law at all (when $1-\varepsilon_{I}-\varepsilon_{I I}<0$ ).
} 
believes that it is not in breach of the law. If such errors are possible, general deterrence becomes less effective and ex post intervention becomes necessary.

This line of reasoning suggests that the importance of general deterrence is overwhelming in the case of cartels, where it is hard for managers to make mistakes in the evaluation of the legitimacy of the practice and over-deterrence is less likely. On the other hand, for vertical agreements subject to a "rule of reason" evaluation, for abuses of dominance and, in particular, for mergers, it is clear that general deterrence can bring along erroneous deterrence of efficient conducts, exactly because it is more difficult to anticipate whether it will be judged anticompetitive by the enforcement agency. Hence, for these more complex infringements it is optimal to allow some under-deterrence and to also rely on specific deterrence. This justifies the main focus of the empirical literature that assesses the correctness of merger control decisions on their likely effects on the specific industry, rather than in terms of general deterrence effects ${ }^{14}$.

\subsection{Deterrence of anticompetitive behaviors: firms rather than individuals}

Since Becker's contribution, competition law enforcement and optimal deterrence of anticompetitive behaviors has become a specific research subject, which has gone well beyond extending or adapting results in the economic theory of the public enforcement of law. For example, competition economists like Werden and Simon ${ }^{15}$ disagreed early and openly with the 'Beckerian' approach to law enforcement, in particular in cartel cases, on the issue of always giving priority to fines over

${ }^{14}$ See T. Duso, N. Damien and L. H. Röller, The Political Economy of European Merger Control: Evidence Using Stock Market Data, 50m (3) The Journal of Law and Economics 455 (2007) and P. Buccirossi, L. Ciari, T. Duso, S.O. Fridolfsson, G. Spagnolo and C. Vitale supra note 12. However, the recent theoretical analysis by L. Sorgard, Optimal merger policy, Manuscript, Norwegian School of Economic and Business Administration and Norwegian Competition Authority (2007), suggests that taking into account the likely deterrence effects of merger control should lead to a rather different interpretation of the results of studies on the ex post evaluation of merger control decisions. If competition policy is effective, it deters ex-ante the clearly anticompetitive mergers, leaving for the scrutiny of competition authorities those that are more difficult to evaluate and for which errors are more likely. This is the expected effect for an effective merger control policy, which deters all clearly anticompetitive mergers and focuses its investigations on difficult cases. Recently, analyses of deterrence in merger control have also been attempted. See for instance J. Seldeslachts, J. Clougherty, and P. Pita Barros, Settle for Now but Block for Tomorrow: The Deterrence Effects of Merger Policy Tools, The Journal of Law and Economics, forthcoming.

${ }^{15}$ See G. J. Werden, M. J. Simon, supra note 1 
imprisonment because the former are less costly to society. ${ }^{16}$

The reason behind the development of a specific literature on enforcement of competition law is that, in this case, the design of the system that ensures optimal deterrence is complicated by the fact that the potential violators are both individuals and firms ${ }^{17}$. Hence, there are a number of additional factors that have to be taken into account. For example, fines - against firms and individual employees - can be relatively less effective than imprisonment of the managers, because firms are protected by limited liability and they can easily indemnify managers by paying their own fines when they acted in the interest of the firm ${ }^{18}$. On the other hand, the design of the optimal sanction against corporations should consider that firms can be sanctioned both by the market ${ }^{19}$ and by the presence of a principal-agent problem between shareholders and managers, and between managers and their subordinates. Indeed anticompetitive behaviors may not stem from calculated profit-seeking decisions at firm level, but may result from the presence of perverse incentives for some employees who derive a personal benefit from an anticompetitive practice (e.g. because their remuneration is linked to a very high sales target ${ }^{20}$. Firms try to prevent these occurrences through compliance systems and changes in decision-making practices. Yet, these activities have a cost that can derive not only from setting up a

\footnotetext{
${ }^{16}$ For a review of the recent debate on the use of criminal sanctions against antitrust violators, spurred by the introduction of leniency programs and reward schemes for whistleblowers, see Buccirossi and Spagnolo, supra note 2.

${ }^{17}$ This is actually true for all corporate crimes.

${ }^{18}$ See A.R. Beckenstein, H.L. Gabel, Antitrust Compliance: Results of a Survey of Legal Opinion, Antitrust Law Journal (1982); B. Kobayashi, Antitrust, Agency and Amnesty: An Economic Analysis of the Criminal Enforcement of the Antitrust Laws Against Corporations, George Mason Univ. Law and Econ., Working Paper No. 02-04, (2002); G. Spagnolo, Stock-Related Compensation and ProductMarket Competition, 31(1) RAND Journal of Economics 22, (2000) and G. Spagnolo, Managerial Incentives and Collusive Behaviour, 49(6) European Economic Review 1501 (2005).

${ }^{19}$ For an overview of these principal agent issues for cartel deterrence see P. Buccirossi and G. Spagnolo, Corporate Governance and Collusive Behavior, in W.D. Collins (Ed.) Issues in Competition Law and Policy, American Bar Association, Antitrust Section, Washington (2008) and for an illuminating formal treatment of the issue see C. Aubert, W. Kovacic, P. Rey, supra note 4

${ }^{20}$ Buccirossi and Spagnolo, supra note 19 argue that if firms become liable for sufficiently high fines, directors should be induced to choose, within their compliance efforts, those executive contracts that deter management from undertaking illegal actions, even if these increase profit. However, as noted in J. Harrington, How do Cartels Operate, Foundations and Trends in Microeconomics (2006), in most cartel cases prosecuted in Europe the illegal agreement was decided at the top management level and almost no CEO was fired after their firm was convicted for price fixing. This suggests that, in Europe, corporate governance systems are not yet designed to dissuade top management from undertaking anticompetitive behaviors. A likely reason for this is that fines and other sanctions have been too low in Europe, making anticompetitive agreements a profitable undertaking for both agents/managers and principals/shareholders.
} 
system that ensure compliance (e.g. hiring legal advisors), but also from the choice to centralize decision-making which reduces a firm's ability to quickly react to market changes. These costs should be taken into account when determining the optimal level of deterrence ${ }^{21}$.

It should also be considered that very high fines may jeopardize a firm's financial stability, in which case they may run against the ultimate goal of competition law: welfare maximization. This consideration is often mentioned in policy debates, as there is a common perception that future competition should increase with the enforcement effort, and that the number of active competitors might be a proxy for the degree of competition. This perception may render very high fines not credible, as agencies and judges may choose not to apply (or to reduce) them when they can seriously jeopardize the existence of a firm. This lack of credibility could in turn reduce their deterrence effect ${ }^{22}$. This argument on bankruptcy, and the policy it appears to foster, has severe limitations, however. As argued by Buccirossi and Spagnolo $^{23}$, there are a number of qualifications that must be taken into account when arguing for caps on antitrust fines that ensure the financial survival of firms. For example, if this concern induces setting fines at too low a level to have a deterrence effect, this may be more costly to society than the risk of driving a few convicted firms bankrupt with higher fines.

Moreover, competition law exists to deter anticompetitive behaviors in all industries. If, for instance, high "optimal” fines provoke the bankruptcy of some convicted firms in an industry, this may temporarily decrease the number of firms in that particular industry, but it may also increase competition in other industries, through the ex-ante general deterrence effect generated by the fines.

${ }^{21}$ See B. Kobayashi, supra note 18 . He claims that if sanctioning tools were further strengthened in the US, where actual fines are high and treble damages can be imposed on misbehaving firms, the result could be higher prices for consumers and a decrease in social welfare. The reason is that, even if large ex-ante penalties can increase ex-ante deterrence, they also induce corporations to incur higher precaution and avoidance costs up to a point where they become excessive relative to social gain they bring about, i.e. they can induce over-enforcement.

${ }^{22}$ C. Craycraft, J.L Craycraft, J. Gallo, supra note 2, find evidence that courts act according to this idea that bankruptcy should be avoided and reduce fines when a firm's ability to pay appears low. They also find that, in the majority of the US cases they analyzed, firms were imposed fines that were only a fraction of the optimal cartel-deterring Beckerian ones, even though these could have afforded to pay them from their normal cash flow.

${ }^{23}$ See Buccirossi and Spagnolo, supra note 2 
In addition, if bankruptcy procedures are efficient, the impact of the financial failure of some convicted firms on competition may be small, or even positive, as the firms driven bankrupt by a fine should be economically sound. Therefore, they might be sold to new owners who can use the same assets to enter the market and compete again.

Most importantly, linking fines to the firms' ability to pay, so as to always avoid bankruptcy, as apparently done by US courts and explicitly recommended by some legal scholars, entails the double risk of generating distorted incentives for compliance for wrongdoers differing only in their financial situation, and of inducing firms to issue more debt to reduce their (apparent) ability to pay and, thereby, the level of the expected fines ${ }^{24}$. Such a policy would add to the social costs of reducing deterrence by allowing limiting the level of the sanctions for competition law violations, also the costs stemming from firms adopting an inefficient financial structure $^{25}$.

\section{The determinants of deterrence in competition law}

Section 2 has highlighted a key point among others: there exist "good” deterrence and "bad” deterrence (i.e. over-deterrence). Good deterrence prevents firms from adopting conducts that, by impairing competition, reduce welfare, while bad deterrence - or over-deterrence - prevents firms from adopting conducts that, by enhancing competition, improve social welfare. A competition policy regime is more effective the higher its level of good deterrence and the lower its level of bad deterrence.

As shown by the previous analysis, both good and bad deterrence depend on three

\footnotetext{
${ }^{24}$ This seems to have already happened in the US with taxi companies trying to limit their liability towards victims of car accidents. See Y. Che \& K. Spier, Strategic Judgment Proofness, Northwestern Univ. Center for the Study of Indus. Org. Working Paper No. 0081, (2006)

${ }^{25}$ With the introduction of new competition policy instruments, such as leniency programs and rewards for whistleblowers, the issue of firms' limited ability to pay loses bite substantially. P. Buccirossi, G.Spagnolo, supra note 2, show through a set of simulations that in the presence of well-designed and consistently/parsimoniously administered leniency and whistleblower rewards programs the deterrence effect of fines increases substantially (too generously administered programs of this kind will clearly reduce deterrence and welfare, though they may make the work of a competition authority much easier). G. Spagnolo, supra note 4 shows that implementing a scheme that rewards the first whistleblower with the fines paid by other wrongdoers, the first best, complete cartel deterrence is optimal in a model à la Becker and is achievable at a finite level of fines. Comparable results are obtained in a more recent theoretical analysis by Z. Chen and P. Rey, On Design of Leniency Programs, IDEI Working Paper, n. 452 (2007).
} 
general features of the legislation and its enforcement:

1) the level of the loss that firms and individuals expect to suffer if they are convicted (rightly or wrongfully);

2) the perceived probability of wrongdoers being detected and convicted;

3) the perceived probability of being wrongly convicted.

It is now important to understand which features of a competition policy regime (i.e. which policy variables) influence the level of deterrence and make the policy more or less effective, by affecting these factors.

In what follows we identify six sets of policy variables that we believe affect the three key elements of deterrence identified in the economic literature and just listed.

3.1 Features that affect the level of the loss: sanction policy, damages and market reaction

One feature of competition law regime that has the most evident impact on its deterrence properties is its sanction policy. The sanction policy has a clear and direct impact on the first of the three general features listed above. Indeed, one of the sources of the loss incurred by a convicted firm is the sanction levied by a competition authority (CA) and/or a court (e.g. fine or imprisonment) for a breach of competition law. However, the total loss suffered by a firm, or by its executives in the case of conviction, is not limited to the sanction. It includes the damage repayments a firm expects to have to pay to the affected parties, as well as any loss in equity value or in market share it may suffer. The latter comprises the loss of customers who are unwilling to trade with a firm that has violated the law, the loss of reputation among clients and/or input suppliers, and the reduction of the stock market value that may affect its ability to raise capital.

It is important to note that it is the sum of all these costs, and not just the sanctions imposed by a CA or a court, that are relevant, because what determines the behavior of a firm are the total gain and losses imposed by a given course of action with respect to alternative ones.

It is also important to highlight that the level of the loss depends on two elements: the law on the books and how this is enforced. The sanctions imposed by the CA (or by a 
court) depend on the criteria set out in the law regarding the type of sanctions and maximum level they can reach, and on how these criteria are actually applied (i.e. their enforcement). For instance, if the monetary fine can reach up to $10 \%$ of the turnover of a firm, but no fine of this level has ever been imposed, even when a serious breach of the law took place, firms will not expect to have to pay such a figure, despite what the law says. Similarly the damages a firm can be expected to pay depend on whether it is legally possible to undertake a private enforcement action, on the legal framework that discipline these actions (e.g. whether class actions are possible or whether there is the treble damage rule) and on how tough courts have been in their decisions.

From this consideration it emerges that competition rules do not operate in isolation and that the characteristics of the judicial system matter substantially. This happens both in those legal systems in which the CA has the power to impose sanctions directly and in those systems in which the CA only has the power to initiate a proceeding, while the amount of the sanction is determined by a court. In both systems judges have the final word on the sanction, since the administrative decisions of competition authorities are also subject to judiciary review.

The role of the judicial system is even more evident in relation to actions for damages. Victims of anticompetitive acts will claim damages only if the prospect of recovering their loss is sufficiently high to compensate their cost of bringing a suit. Both the expected gain of the action and its expected cost are affected by the effectiveness of the judicial system.

Stock market reactions, instead, do not depend on any law, but on the response of markets to the convictions. Therefore it does not refer to some specific policy variables, but rather to a more diffuse set of social norms that may be influenced by many policies.

\subsection{Features that affect the probability of detection and conviction}

The probability agents attribute to the occurrence of being apprehended after breaching the law depends mostly on the policing activity of the CA. This can be defined by the "level" and "method" of such activities: the amount of resources the CA devotes to this activity, and the powers it holds. Before very briefly discussing 
these elements, we need to point out that some aspects of the sanction policy may also alter the probability of detection. This occurs through the leniency programs that grant immunity to those firms that reveal the existence of a cartel. One of the deterrence effects of leniency programs works precisely through a modification of the perceived probability that a cartel is uncovered by a CA, as the incentive firms have to cooperate with the enforcer improves the chance that the latter will discover illegal activities that would have otherwise remained unknown ${ }^{26}$.

\subsubsection{Financial and human resources}

The level of enforcement of a competition law is a direct result of the financial and human resources that the CA can employ. The higher the amount of the resources, the more likely it is that the competition authority will become aware of conducts that can impair competition. This positive relationship between resources, effort and the probability of uncovering illegal conducts seems quite obvious and does not seem to deserve further discussion.

\subsubsection{Powers during investigation}

A different policy dimension that affects the probability of detection and conviction is the type of investigative powers held by the CA. The stronger these powers, the better the information the CA can gather. These powers, in addition to the ability to inspect the premises of the firm under investigation, can include the ability to inspect private premises of their employees or the ability to wiretap their conversations. We believe that the existence of a positive relationship between the extent of the investigative powers and the probability of uncovering illegal conducts is also quite obvious and that any further consideration is unwarranted ${ }^{27}$.

\subsection{Features that affect the probability of errors}

The features discussed in the previous subsection are likely to affect not only the

\footnotetext{
${ }^{26}$ G. Spagnolo, supra note 5.

${ }^{27}$ With respect to the financial and human resources and to the investigative powers, of course we are not claiming that from a social point of view it is optimal to set them at their maximum feasible level; we just maintain that there is a monotone positive relations between them and the (perceived) probability of crime detection.
} 
"quantity" of the enforcement activities, but also their "quality”. If more accurate information is available, the CA is less likely to commit errors of both types ${ }^{28}$. Some characteristics of the sanction policy can also improve the ability of the CA to meet the standard of proof needed to legally prove anticompetitive conducts. Once again, leniency programs, when combined with adequate sanctions, can reduce the probability of errors. Full or partial leniency is usually granted if the self-reporting firm provides evidence that contributes to the formation of a legal proof of the agreement or that allows the CA to understand more clearly its functioning and its impact on the market. The evidence provided by the leniency applicant strengthens the case and reduces the probability that firms that are actually guilty are acquitted by the CA or in subsequent judgments.

The probability of errors depends on many, and various, other features of a competition policy regime. They are briefly discussed below.

\subsubsection{Quality of the law}

So far we have defined deterrence and over-deterrence with reference to the prevention of conducts that reduce or enhance social welfare. However, these may not be the conducts that are declared illegal or legal by the competition legislation. Rules are indeed imperfect as they can ban competitive conducts (leading to type I errors) or allow anticompetitive conducts (leading to type II errors).

The quality of the rules is a matter of judgement, which makes defining this policy variable extremely difficult. However, one can observe whether the competition legislation (and the soft law that disciplines its actual application, e.g. guidelines) has rules that make the partition between legal and illegal conducts closer to their effect on social welfare, according to the prevalent economic theory. Key factors, for instance, are: whether the competition law allows an efficiency defense for mergers, whether the CA can consider non economic goals in evaluating the effects of potentially abusive behaviors, whether the standard of proof is based on a rule of reason or a per se prohibition and whether there is a general exemption for one or more industries.

\footnotetext{
${ }^{28}$ J. Lagerlöf and P. Heidhues, “On the Desirability of an Efficiency Defense in Merger Control”, 23 International Journal of Industrial Organization 803 (2005)
} 


\subsubsection{Independence}

A further relevant factor that affects the deterrence properties of a competition policy regime is the independence of the CA with respect to political or economic interests. A CA that makes its decisions by taking into account interests that are (potentially) in contrast with those that should guide its activity is more likely to commit errors of both types ${ }^{29}$.

Important elements for determining the level of independence of a CA are its institutional status (i.e. whether it is a court, an independent public sector body or a branch of a ministry) and whether the government has the power to over-rule a decision taken by the CA.

Ideally, one should consider not only the level of formal independence of a CA, i.e. as guaranteed by the legal framework, but also the level of effective independence, which depends on its actual ability to avoid interference and capture from the government or the business community. Unfortunately, the latter is more difficult to assess, as it cannot be ascertained from the legal set-up This can only be evaluated by eliciting the views of businesses or of their legal and economic advisors, but these opinions may be biased by many factors, including the method used to solicit them, and may make it difficult to have meaningful data to perform any comparison across

\footnotetext{
${ }^{29}$ For a discussion of the importance of having a CA that is independent of the government see P. Rey, Toward a Theory of Competition Policy, in Advances in Economics and Econometrics: Theory and Applications - Eight World Congress, M. Dewatripont, L. P. Hansen and S. J. Turnovsky (eds.), series "Econometric Society Monographs", vol. II, n. 36, Cambridge University Press, 82-132, (2003).;S. Voigt, The Economic Effects of Competition Policy - Cross-Country Evidence Using Four New Indicators, International Society for New Institutional Economics Working Paper 9.3 (2006); G. Oliveira, E. Luiz Machado, C. B. Guimarães Ferreira, L. M. Novaesm, Aspects of the Independence of Regulatory Agencies and Competition Advocacy, ICN-Bonn Working Paper, III Subgroup (2005); OECD, Designing Independent and Accountable Regulatory Authorities for High Quality Regulation (2005); OECD, European Commission - Peer Review of Competition Law and Policy (2005); J.Høj, Competition Law and Policy Indicators for the OECD countries, OECD Economics Department Working Papers, No. 568 (2007); Moreover a CA makes decisions that pursue its true objective if it is not influenced by the "regulated" firms, as argued by the vast literature on the so-called "regulatory capture” (See G. Stigler, The theory of economic regulation. Bell J. Econ. Man. Sci. 2:3-21 (1971); S. Peltzman, Toward a More General Theory of Regulation, 19(2) The Journal of Law and Economics 211 (1976); R. A. Posner, Taxation by Regulation, 2(1) The Bell Journal of Economics and Management Science 22 (1971); R. A. Posner, Theories of Economic Regulation, 5(2) The Bell Journal of Economics and Management Science 335 (1974); R. A. Posner, The Social Costs of Monopoly and Regulation, 83(4) The Journal of Political Economy 807 (1975); G. Becker, A Theory of Competition Among Pressure Groups for Political Influence, 98(3) The Quarterly Journal of Economics 371 (1983); J.J. Laffont and J. Tirole, 106(4) The politics of government decision making. A theory of regulatory capture, Quarterly Journal of Economics 1089 (1991).
} 
countries.

\subsubsection{Separation of powers}

One final relevant characteristic is the degree of separation between the body that performs the investigation on an allegedly anticompetitive behavior and the one which takes the decision on whether the behavior should be sanctioned. The stronger the separation between prosecutor and adjudicator (e.g. when the investigation is made by an independent public body and the decision by a court) the more balanced the decision is likely to be. This, in turn, lowers the probability of an error ${ }^{30}$. Similarly, it matters whether the appeal court is a specialized body with competence only on competition matters or whether it is the appeal body for all judicial decisions, and how long the appeal procedures are ${ }^{31}$.

\subsection{Conclusions on the determinants of deterrence}

We believe that the six sets of policy variables described above include the main institutional and enforcement aspects on which deterrence of anticompetitive practices depends. To summarize, they are: 1) sanctions and damages; 2) financial and human resources; 3) powers during the investigation; 4) quality of the law; 5) independence; and 6) separation of power.

There are, of course, other determinants of deterrence that do not fall among the six categories discussed above. For example, when a cartel is international in scope and leniency policies are not coordinated across countries and agencies, the risk for the first whistleblower in a country to be the second one (hence, obtaining reduced or no leniency) in other countries because cartel partners reacted to the reporting by rushing to self-report elsewhere may clearly hinder the deterrence effects of leniency programs. Moreover, as we have already pointed out, the deterrence properties of a

${ }^{30}$ See M. Block, J. Parker, O. Vyborna and L. Dusek, An experimental comparison of adversarial versus inquisitorial procedural regimes, 2(1) American Law and Economics Review 170 (2000); M. Dewatripont and J. Tirole, Advocates, 107(1) Journal of Political Economy 1 (1999); D. J. Neven and L. H. Röller Consumer Surplus vs. Welfare Standard in a Political Economy Model of Merger Control, 23 (9-10) International Journal of Industrial Organization 829 (2005); R. Posner, Comment: Responding to Gordon Tullock, 2 Research in Law and Policy Studies 29 (1988); W. Wils, The combination of the investigative and prosecutorial function and the adjudicative function in EC antitrust enforcement: a legal and economic analysis, 27(2) World Competition 201 (2004)

${ }^{31}$ See OECD, Relationship between competition policy and economic performance, Paris (2005). 
competition policy regime depends on the quality of the judiciary system and of the institutions in general, as well as on the type of social norms that guide the conducts of agents in each context.

\section{Measuring deterrence}

Measuring deterrence is an extremely difficult task because the deterrent effect implies that firms choose a different behavior from the one they would have adopted without a competition legislation and its enforcement. To measure this effect one would have to be able to determine the actions that firms would have undertaken had they not been constrained by the risk of a sanction, which means measuring the occurrence of certain events in a pure and only hypothetical world.

Any researcher who wants to measure the level of deterrence of the enforcement of a given law or regulation faces this type of problem, because it is impossible to directly observe intentions if these do not materialize into actions. In some cases it is possible to study how the number of breaches has changed over time when there has been a change in the level of the sanction, in the probability of detection or in the enforcement effort. For example, if the length of the maximum imprisonment sentence for a house theft is increased, it is possible to measure its deterrence effect by measuring the change in the rate of break-ins. However, calculating the rate of change is possible only if one has a reliable knowledge of the total number of violations committed in a given period of time. In the case of crimes like bank robberies or homicides, understanding if their total number has changed is relatively easy because most of them are reported to the police. The same does not apply to competition law breaches, a large share of which might go undetected.

Among the different types of anticompetitive practices cartels are the most problematic, because only a fraction of them is likely to be detected. This is especially true when cartels take place in retail markets, where it is hard for asymmetrically informed and often dispersed consumers to realize whether they paid a competitive or a collusive price. Hence, the level of deterrence on cartels cannot be measured by direct observation.

The abuses of a dominant position and anticompetitive agreements other than cartels, instead, tend to be reported more often, because they tend to affect a limited number 
of large players, who are, in general, aware of the obligations imposed on dominant firms. However, because of the difficulties faced by firms in judging whether a given behavior is pro- or anticompetitive there is a high risk of over-reporting.

As for anticompetitive mergers, if there is an obligation to notify, there are data on the total number of mergers and on the share that are blocked. In this case, direct observation of the degree of deterrence may be possible. However, the number of blocked mergers may underestimate the number of anticompetitive concentrations because a large share of mergers do not yield the efficiency effects forecasted.

In conclusion, measuring the deterrence effect of competition policy on the behaviors of firms and their managers is a rather complex task. The remainder of this section reviews the literature on the subject. We first examine those papers that have tried to assess the deterrent effect of competition policy on cartels and abuses, and then consider the papers on deterrence and merger control policies.

\subsection{Agreements and unilateral conducts}

There are very few studies that try to ascertain the level of compliance with competition law, and hence its deterrence effect, and to understand the factors that influence it. A large part of these are based on surveys, of the regulatees or of their legal advisors, that attempt to measure the intentions of firms and their managers with regard to anticompetitive practices and how these have been altered by competition policy. These studies obtain mostly qualitative results, but provide some useful insights on the determinants of compliance with competition law.

Beckenstein and Gable ${ }^{32}$ provide the results of a survey of all US antitrust practitioners (external and in-house ones) on changes in the frequency of violations of the Sherman Act and on the causes that led firms to commit them, as well as on the methods adopted by firms to ensure compliance with the law. The responses refer to the period from the late 50 s to the late 70 s.

Their results show that ignorance of the law was initially the main source of violations, but that its relevance decreased over time, while pursuit of corporate gain

\footnotetext{
32 See A.R. Beckenstein, H.L. Gabel, The Economics of Antitrust Compliance, 52(3) Southern
} Economic Journal 673 (1986). 
rose to become the main cause of anticompetitive practices. Ambiguity of the law also scored high among the causes of breaches of Section 2 (prohibition of attempts to monopolize, which is akin to Art.82 of the EU Treaty), but not of Section 1 (prohibition to form cartels). The survey did not report any major change in the frequency of violations, even though the degree of enforcement was seen as increasing. Furthermore, the respondents perceived the probability of a cartel being detected as much lower than the probability that an attempt to monopolize was discovered. The most powerful deterrence instruments were considered to be the risk of imprisonment and the threat of private suits for damages, followed by fines and the cost of the court cases (which, at the time, was substantially smaller than today).

Around the same time, Feinberg ${ }^{33}$ explored the effects of the EU competition policy on horizontal agreements and parallel imports in the Member States, relying on an anonymous survey of the opinions of antitrust practitioners based in Brussels. The survey was run in the early 1980s, ten years after the EU Commission introduced financial penalties for breaches of Art. 81, and examined the changes it brought about. The key results reported by Feinberg are that: 1) the risk of being investigated and sanctioned by the EU Commission was seen has having increased since the late 1970s and as having a deterrent value, 2) there was no agreement on whether antitrust violations were more or less common than ten years before, 3) there was general agreement that the Commission failed to detect most of these violations, 4) ambiguity of the law was never seen as a major source of anticompetitive behaviors, while the most common cause was considered to be the pursuit of corporate gain. The suggestions put forward by the respondents to promote compliance were: higher fines, the encouragement of private damage suits and the imposition of penalties on the managers of the offending firms.

A slightly different approach has been followed by Nielsen and Parker ${ }^{34}$, who surveyed the regulatees, rather than their advisors. In their paper the two authors describe the responses obtained from questioning a sample of Australian firms on their level of compliance with the Trade Practice Act (the Australian competition and

\footnotetext{
${ }^{33}$ See R.M. Feinberg, The Enforcement and Effects of European Competition Policy: Results of a Survey of Legal Opinion, 23(4) Journal of Common Market Studies 373 (1985).

${ }^{34}$ See V. L. Nielsen, C. Parker, The ACCC Enforcement and Compliance Survey: Report of Preliminary Findings (2005).
} 
consumer legislation). Their key findings are that most businesses claim a high degree of actual compliance with the Act, as well as a high level of agreement with its values and a motivation to comply with it. The respondents also rate highly the threat of regulatory enforcement action. The authors measure the extent of this threat by asking firms their views about the clarity of the Act, about the quality of the Australian CA's resources, and about the likelihood of enforcement action against violators of the Act. Nielsen and Parker ${ }^{35}$ also find that there is not much variation across industries in terms of level of compliance, while the size of the firm matters, as larger businesses exhibit a higher level of compliance and greater awareness of the rules than the smaller firms. This can be due to their having more resources to implement compliance systems, to their feeling more vulnerable to the threat of regulatory enforcement, and/or to their being more likely to have already been subjected to an investigation by the Australian Competition and Consumer Commission.

More recently, some CAs have directed their attention to the issue of deterrence (see also section 4.2). The UK Office of Fair Trading ${ }^{36}$ undertook a study aimed at understanding how effective the role of the two UK CAs has been in promoting competition. As part of this study it ran a survey of antitrust lawyers and in-house legal advisors to assess the level of deterrence and over-deterrence the competition law enforcement generates in the UK, as well as the key factors that influence business compliance (e.g. which types of sanctions are most feared and what is the influence of past decisions). The results of this study show that the deterrent effect in the UK is quite high, in particular for cartels and other anticompetitive agreements and less so for abuses of a dominant position.

The study found that companies abandoned, or significantly modified, a large number of possible anticompetitive agreements and conduct because of the risk of an OFT investigation. The survey of antitrust lawyers suggests the following ratios of agreements and initiatives abandoned, or significantly modified, to those which resulted in a Competition Act decision by the OFT over the period 2000-06: cartels 5 : 1 , commercial agreements $7: 1$, and abuses $4: 1$. These ratios should be interpreted as lower bounds for two reasons: 1) external legal advice is generally sought only at a

\footnotetext{
${ }^{35}$ See V. L. Nielsen, C. Parker, supra note 34.

${ }^{36}$ See OFT, Productivity and competition, OFT887 (2007).
} 
late stage in any business planning and, hence, there is deterred activity on which external advice is never taken; and 2) they are based on the assumption that on average the same number of lawyers are consulted. Indeed the company survey produced significantly larger ratios: cartels 16:1, commercial agreements 29:1, and abuses 10:1

In both the legal and the company surveys, the researchers asked whether respondents had any suggestions for improving the deterrence of competition law infringements in the UK. The suggestions most frequently made were: spending more on publicity and educational campaigns, encouraging private damages actions, speeding up the decision taking process, increasing the number of criminal prosecutions for cartels and augmenting the enforcement activity.

In addition to the OFT study, another attempt to quantify the deterrent effect of competition policy has been made by the US Department of Justice ${ }^{37}$. Again, on the basis of the results of a survey, it concluded that, if it stopped enforcing Section 1 of the Sherman Act, there would be an estimated 150 percent increase in the number of conspiracies over the following five years, and an increase (not quantified) in the aggressiveness of those conspiracies.

\subsubsection{Assessing the deterrence effects of competition policy on cartels using hard data}

All the studies just mentioned are based on surveys and have obtained very limited quantitative results on the level of deterrence, and these represent only lower bound estimates. A few other studies exist that are based on other analytical tools.

There is a study, commissioned by the OFT to Davies and Majumdar ${ }^{38}$, which attempts to quantify the deterrent effect of competition policy on cartels by relying on empirical findings made in other studies. The two authors conclude that, on the reasonable assumption that typical demand elasticities are less than 8.5 , it is possible to say that competition policy has a non-trivial deterrent effect on cartels and this could be very substantial, at the very extreme leading to an actual price of about oneseventh of the full monopoly price that would prevail without competition policy.

${ }^{37}$ See DoJ, Antitrust Division Congressional Submission for Fiscal Year 2001, Washington DC: US Department of Justice (2000)

38 See S. Davies, A. Majumdar, The development of targets for consumer savings arising from competition policy, OFT Economic Discussion Paper 4. 
More recently there have been some attempts to evaluate the likely deterrence effect of leniency programs using econometric methods. Brenner ${ }^{39}$, for example, estimates the relationship between leniency applications, the size of the fines actually imposed, and the duration of the investigations for the cases in which the EU 1996 leniency notice was employed (which was considered not very effective and revised in 2002). The study assumes that higher fines signal, ceteris paribus, that better information was available to the prosecution, and finds that the program did help to elicit information from cartel participants, but that it did not increase deterrence. Indeed, it concludes that the EU leniency program had no significant effects on the hazard rate at which cartels break down, nor on their expected duration.

Miller $^{40}$ estimates the likely impact on deterrence of the unanticipated introduction of a leniency program by looking at variations in the number of cartels discovered. Miller applies his methodology to all the cartel indictments that took place in the US between 1985 and 2005, and finds that the introduction of the leniency program is likely to have considerably enhanced the detection and deterrence ability of the DoJ. He estimates that over that period the cartel detection rate increased by about $62 \%$, and that the rate of cartel formation fell by about 59\%. Surprisingly, he also finds that the spike in cartel discovery occurred slightly before the introduction of the leniency program, and that the increased protection from damage suits for leniency applicants (de-trebling of damages) and the strong increase in sanctions for other cartel members, introduced by the Antitrust Criminal Penalty Enhancement and the Reform Act in 2004, did not have any significant effect on the number of cartels uncovered.

\subsection{Mergers}

The deterrence effect of merger control policies have also been studied through surveys. Aaronson ${ }^{41}$ describes a survey of the Times top 500 firms, run by Coopers and Lybrand in 1991, on their perception of the activity of the UK CAs. He reports

\footnotetext{
${ }^{39}$ See S. Brenner, An empirical study of the European corporate leniency program, forthcoming in the International Journal of Industrial Organization.. See also the methodological work of J. Harrington and M.H. Chang, Modelling the birth and death of cartels with an application to evaluating antitrust policy, forthcoming in the Journal of the European Economic Association.

${ }^{40}$ See N. Miller, Strategic Leniency and Cartel Enforcement, forthcoming in the American Economic Review.

${ }^{41}$ See R. Aaronson, Do companies take any notice of competition policy?, 2(3) Consumer Policy Review 140 (1992).
} 
only the results relative to mergers, but the questionnaire also covered other areas of competition policy. From these results he concludes that competition policy has a low deterrent effect because of a combination of limited knowledge of the rules among top managers and of a lack of clarity about the criteria followed by the two CAs in reaching decisions (both around 40\%). However, since the questions were asked, the degree and the quality of communication between the agencies and the regulatees in the UK have improved substantially.

More recently the Dutch Competition Authority ${ }^{42}$ undertook a research into the nature and magnitude of the ex-ante, or general, deterrence effect, which they call the "anticipation effect", of the enforcement of the merger control legislation, i.e. the extent to which firms decide against certain mergers or do not consider certain options because they expect not to receive the NMa’s approval.

The research involved a survey of 16 competition lawyers, followed by a further set of interviews with firms, investment banks and private equity companies. Its main conclusion is that firms are aware of the merger control legislation and try to predict and minimize NMa's possible interventions. The effect manifests itself at different stages in the evaluation of a possible merger by the firms and by their legal advisors. Mergers that have a high likelihood of a prohibition are not even considered (and often lawyers are not even consulted on these), while in the past firms did try to go ahead with more "problematic" mergers. Once the idea of a merger develops into a more thought-through "initiative" it is much less frequent that this is abandoned because of the risk of an NMa's intervention, but it is likely that the merger is altered so as to minimize the possibility of competition problems.

The OFT study previously mentioned also devoted some attention to mergers. The survey of antitrust lawyers suggested that, over the period 2004-06, at least five proposed mergers were abandoned, or modified, on competition grounds before the OFT became aware of them, for each one merger blocked or modified following intervention by one of the UK competition authorities. The company survey suggested that a merger is more likely to be abandoned or modified if there had been a recent CC inquiry in the sector.

\footnotetext{
${ }^{42}$ See NMa, Research into the Anticipation of merger Control, (2005).
} 
4.2.1 Assessing the deterrence effects of merger control using hard data

Very few papers try to assess the deterrence effects of competition policy on mergers using hard data. An exercise of this type was performed in the mid-60s by Stigler ${ }^{43}$. He identifies a "composition" deterrence effect, as he finds that the fraction of horizontal mergers fell relative to that of conglomerate and vertical ones, after the US merger control procedure became tougher in the 1950s.

More recently Seldeslachts et al. ${ }^{44}$ focus on the impact of different policy tools on the deterrence of mergers. The hypotheses their study aims to test are that: 1) an increase in the number of prohibited mergers leads to a decrease in the number of attempted mergers; and 2) a rise in the number of mergers that are allowed conditioned to specific behavioral, or structural, remedies increases the number of mergers notified, when the imposition of remedies substitutes a prohibition, while it decreases their number when the imposition of remedies substitutes an unconditional clearance.

In order to test these hypotheses, the authors use a unique cross-country dataset on merger decisions relative to the 1992-2003 period in 28 OECD countries. The deterrence effect is measured by the change in the number of mergers that are notified to the competition authorities. The main explanatory variables are given by the level of the several possible "antitrust actions", i.e. the number of "prohibitions", the number of "authorizations with remedies", and the number of "authorization with a commitment by the CA to monitor the post-merger behavior". To ensure that the estimation results can be interpreted in a causal way, they control for: the lagged number of mergers (since mergers occur in waves), any modification in the threshold that triggers the obligation to notify the merger, economic growth (measured by the percentage variation of the country's GDP), and the degree of capitalization of the listed companies as a percentage of the country's GDP.

Their findings provide strong support for the first hypothesis, i.e. that prohibitions have a deterrence effect on future merger frequencies, but not for the second one, because the imposition of remedies appears to be less effective in deterring future mergers. However, the authors do not discuss whether the level of deterrence

\footnotetext{
${ }^{43}$ See G. Stigler, The Economic Effects of the Antitrust Laws, 9 Journal of Law and Economics 225 (1966).

${ }^{44}$ See J. Seldeslachts, J. Clougherty, and P.P. Barros, supra note 14.
} 
engendered by the prohibitions is the desirable one, i.e. whether it causes bad deterrence. They only show that an increase in the number of mergers that had been prohibited in the recent past induces firms to attempt a lower number of mergers, but cannot say if this deterrence is of the "good" or of the "bad" type.

In a subsequent paper ${ }^{45} \mathrm{~J}$. Clougherty and J. Seldeslachts employ the dominant deterrence methodology from the crime and punishment literature spawned by Becker $^{46}$ based on conditional probabilities. They aim to eliciting whether different merger policy instruments (investigations, remedies and prohibitions) entail deterrence effects with regard to the composition of proposed merger activity in industrial sectors, as in the original study by Stigler ${ }^{47}$. They use data from the Annual Reports by the U.S. DOJ and FTC which allow industry-based measures over the 1986-1999 period. They show that the composition of horizontal merger activity is negatively influenced by the application of past antitrust actions more than by past antitrust investigations. In particular, they find both the conditional probability of detection (eliciting an investigation), and even more so the conditional probability of punishment (eliciting an antitrust action) to yield deterrence effects on the relative number of horizontal mergers in subsequent years. However, the conditional probability of eliciting a severe punishment (prohibitions versus remedies) does not indicate significant deterrence. Furthermore, their results, in contrast with their previous findings, suggest that there is no significant difference in the deterrence effect of prohibitions and remedies.

\subsection{Conclusions on how to measure deterrence}

Overall, the results contained in the existing literature on the level of deterrence are very limited. There seems to be a general agreement on the fact that the pursuit of gain is the main cause behind any competition law's violation, which suggests that an appropriate sanctioning policy should have a good deterrent effect. Indeed, the respondents to those surveys that ask what could increase compliance suggest higher

\footnotetext{
45 J. Clougherty and J. Seldeslachts, Deterrence of Horizontal Mergers: Empirical Evidence from U.S. Industries, mimeo Wissenschaftszentrum Berlin,

${ }^{46}$ See Becker supra note 6.

${ }^{47}$ See Stigler supra note 43.
} 
fines, a greater opportunity to bring damage actions, and harsher penalties for the individuals involved. In addition, ambiguity of the law is quoted as another important cause behind abuses of a dominant position, which suggests that ex post deterrence can also play an important role with respect to these infringements. With respect to mergers, prohibitions seem to be more effective than remedies and the existence of a merger control procedure seems to curb the number of anticompetitive deals that are attempted.

\section{Conclusions}

To what extent a competition policy regime is able to deter true anticompetitive behaviors is key to its effectiveness. Notwithstanding this obvious proposition, the deterrence properties of the institutional and enforcement features of a competition legislation need further research. In this paper we have tried to provide a comprehensive picture of the subject matter. On the basis of the general economic theory of law enforcement and on its application to the enforcement of competition law we have identified several factors that are likely to affect the degree of deterrence of a competition policy regime. In our opinion, the main institutional and enforcement feature on which deterrence of anticompetitive practices depends are: 1) sanctions and damages; 2) financial and human resources; 3) powers during the investigation; 4) quality of the law; 5) independence; and 6) separation of power. They influence the level of the loss agents are expected to bear when breaching the law, the perceived probability of detection and the perceived probability of errors by the competent CA. Deterrence is also influenced by other general features of the context in which the competition legislation is applied such as the quality of the judiciary system and of other institutions and the type of social norms that guide the conducts of economic actors.

A much more complex issue is how to measure deterrence of anticompetitive behaviors. Most of the attempts to measure deterrence made so far are based on surveys. This is because, especially for non-merger infringements, this method is the only way to obtain direct information on changes in the behavior of firms due to the threats posed by the enforcement of antitrust rules. Surveys have many limitations, which are due to the risk of biased responses and to the difficulty of comparing results across countries. Some researchers have tried to measure deterrence through hard 
data, but this literature is still very limited and new research is definitely needed to improve our understanding of the phenomenon.

Finally, the most challenging task, both theoretically and empirically, is how to distinguish between "good” deterrence and "bad” deterrence. We have identified the features of a competition policy regime that make deterrence stronger. However, this does not mean that any change of these features that increase deterrence is socially desirable. Indeed, more deterrence is needed if and only if the current features of a competition policy regime lead to under-deterrence. If, on the contrary, firms are already over-deterred the competition policy regime should be changed so as to make the threat of its enforcement less harsh. Our current understanding of this last topic is to be judged completely unsatisfactory. 
Bücher des Schwerpunkts Märkte und Politik

Books of the Research Area Markets and Politics

Kai A. Konrad, Tim Lohse (Eds.)

Einnahmen- und Steuerpolitik in Europa:

Herausforderungen und Chancen

2009, Peter Lang Verlag

Kai A. Konrad

Strategy and Dynamics in Contests

2009, Oxford University Press

Roger D. Congleton, Arye L. Hillman, Kai A. Konrad

(Eds.)

40 Years of Research on Rent Seeking

2008, Springer

Kai A. Konrad, Beate Jochimsen (Eds.)

Föderalismuskommission II:

Neuordnung von Autonomie und Verantwortung

2008, Peter Lang Verlag

Mark Gradstein, Kai A. Konrad (Eds.)

Institutions and Norms in Economic Development

2007, MIT Press

Johannes Münster

Mobbers, Robbers, and Warriors

2007, Shaker Verlag

Kai A. Konrad, Beate Jochimsen (Eds.)

Der Föderalstaat nach dem Berlin-Urteil

2007, Peter Lang Verlag

Kai A. Konrad, Beate Jochimsen (Eds.)

Finanzkrise im Bundesstaat

2006, Peter Lang Verlag

Robert Nuscheler

On Competition and Regulation in Health Care

Systems

2005, Peter Lang Verlag

Pablo Beramendi

Decentralization and Income Inequality

2003, Madrid: Juan March Institute

Thomas R. Cusack

A National Challenge at the Local Level: Citizens, Elites and Institutions in Reunified Germany 2003, Ashgate

Sebastian Kessing

Essays on Employment Protection

2003, Freie Universität Berlin

http://www.diss.fu-berlin.de/2003/202

Daniel Krähmer

On Learning and Information in Markets and

Organizations

2003, Shaker Verlag

Tomaso Duso

The Political Economy of the Regulatory Process:

An Empirical Approach

Humboldt-University Dissertation, 2002, Berlin, http://edoc.hu-berlin.de/dissertationen/duso-tomaso2002-07-17/PDF/Duso.pdf
Bob Hancké

Large Firms and Institutional Change. Industrial Renewal and Economic Restructuring in France 2002, Oxford University Press

Andreas Stephan

Essays on the Contribution of Public Infrastructure to Private: Production and its Political Economy

2002, dissertation.de

Peter A. Hall, David Soskice (Eds.)

Varieties of Capitalism

2001, Oxford University Press

Hans Mewis

Essays on Herd Behavior and Strategic Delegation

2001, Shaker Verlag

Andreas Moerke

Organisationslernen über Netzwerke - Die

personellen Verflechtungen von Führungsgremien japanischer Aktiengesellschaften

2001, Deutscher Universitäts-Verlag

Silke Neubauer

Multimarket Contact and Organizational Design

2001, Deutscher Universitäts-Verlag

Lars-Hendrik Röller, Christian Wey (Eds.)

Die Soziale Marktwirtschaft in der neuen

Weltwirtschaft, WZB Jahrbuch 2001

2001, edition sigma

Michael Tröge

Competition in Credit Markets: A Theoretic

Analysis

2001, Deutscher Universitäts-Verlag

Torben Iversen, Jonas Pontusson, David Soskice

(Eds.)

Unions, Employers, and Central Banks

2000, Cambridge University Press

Tobias Miarka

Financial Intermediation and Deregulation:

A Critical Analysis of Japanese Bank-Firm-

Relationships

2000, Physica-Verlag

Rita Zobel

Beschäftigungsveränderungen und organisationales Lernen in japanischen

Industriengesellschaften

2000, Humboldt-Universität zu Berlin

http://dochost.rz.hu-berlin.de/dissertationen/zobel-rita2000-06-19

Jos Jansen

Essays on Incentives in Regulation and Innovation 2000, Tilburg University 


\section{DISCUSSION PAPERS 2008}

Dan Kovenock Brian Roberson

Dan Kovenock Brian Roberson

Vito Tanzi

Kai A. Konrad Kjell Erik Lommerud

Benny Geys Jan Vermeir

Benny Geys Jan Vermeir

Kai A. Konrad Dan Kovenock

Johannes Münster

Kai A. Konrad Dan Kovenock

Kai A. Konrad

Florian Morath

Joseph Clougherty

Anming Zhang

Jonathan Beck

Susanne Prantl

Jo Seldeslachts

Tomaso Duso

Enrico Pennings

Dan Kovenock Brian Roberson

Joseph Clougherty

Tomaso Duso

Benny Geys

Wim Moesen

Benny Geys

Friedrich Heinemann

Alexander Kalb

Johannes Münster

Benny Geys

Wim Moesen
Inefficient Redistribution and Inefficient

Redistributive Politics

Coalitional Colonel Blotto Games with Application to the Economics of Alliances

The Future of Fiscal Federalism

Love and Taxes - and Matching Institutions

Party Cues and Yardstick Voting

The Political Cost of Taxation:

New Evidence from German Popularity Ratings

The Alliance Formation Puzzle and Capacity

Constraints

Repeated Contests with Asymmetric Information

Competition for FDI with Vintage Investment and

Agglomeration Advantages

Non-binding Minimum Taxes May Foster Tax Competition

Strategic Information Acquisition and the Mitigation of Global Warming

Domestic Rivalry and Export Performance: Theory and Evidence from International Airline Markets

Diderot's Rule

The Role of Policies Supporting New Firms:

An Evaluation for Germany after Reunification

On the Stability of Research Joint Ventures: Implications for Collusion

Is the $\mathbf{5 0 - S t a t e}$ Strategy Optimal?

The Impact of Horizontal Mergers on Rivals:

Gains to Being Left Outside a Merger

Exploring Sources of Local Government Technical Inefficiency: Evidence from Flemish Municipalities

Local Governments in the Wake of Demographic Change: Evidence from German Municipalities

\section{Group Contest Success Functions}

Measuring Local Government Technical (In)efficiency: An Application and Comparison of FDH, DEA and Econometric Approaches
SP || $2008-16$

SP || $2008-01$

SP || $2008-02$

SP || $2008-03$

SP II $2008-04$

SP II $2008-05$

SP II 2008- 06

SP || 2008- 07

SP II $2008-08$

SP II $2008-09$

SP || $2008-10$

SP || $2008-11$

SP || $2008-12$

SP || $2008-13$

SP || 2008 - 14

SP || $2008-15$

SP || $2008-17$

SP || 2008- 18

SP II $2008-19$

SP II $2008-20$

SP II $2008-21$ 


\section{DISCUSSION PAPERS 2009}

\section{Áron Kiss \\ Benny Geys \\ Friedrich Heinemann \\ Alexander Kalb \\ Salmai Qari \\ Kai A. Konrad \\ Benny Geys \\ Kai A. Konrad Salmai Qari \\ Sven Chojnacki \\ Nils Metternich Johannes Münster \\ Oliver Gürtler Johannes Münster \\ Dan Kovenock Brian Roberson \\ Subhasish M. Chowdhury \\ Dan Kovenock Roman M. Sheremeta \\ Michael R. Baye Dan Kovenock Casper G. de Vries \\ Florian Morath Johannes Münster \\ Benny Geys}

Paolo Buccirossi

Lorenzo Ciari

Tomaso Duso

Giancarlo Spagnolo

Cristiana Vitale

Pedro P. Barros Joseph Clougherty

Jo Seldeslachts

Paolo Buccirossi Lorenzo Ciari Tomaso Duso Giancarlo Spagnolo Cristiana Vitale
Coalition Politics and Accountability

Voter Involvement, Fiscal Autonomy and Public Sector Efficiency: Evidence from German Municipalities

Patriotism, Taxation and International Mobility

The Last Refuge of a Scoundrel? Patriotism and Tax Compliance

Mercenaries in Civil Wars, $\mathbf{1 9 5 0 - 2 0 0 0}$

Sabotage in Dynamic Tournaments

Non-Partisan 'Get-Out-the-Vote' Efforts and Policy Outcomes

An Experimental Investigation of Colonel Blotto Games

Contests with Rank-Order Spillovers

Information Acquisition in Conflicts

Wars, Presidents and Popularity: The Political Cost(s) of War Re-examined

Competition policy and productivity growth: An empirical assessment

How to Measure the Deterrence Effects of Merger Policy: Frequency or Composition?

Deterrence in Competition Law
SP || $2009-01$

SP || 2009- 02

SP I| $2009-03$

SP II 2009-04

SP || $2009-05$

SP II $2009-06$

SP || $2009-07$

SP I| $2009-08$

SP II $2009-09$

SP II $2009-10$

SP II 2009- 11

SP || $2009-12$

SP || $2009-13$

SP II 2009- 14 
Bei Ihren Bestellungen von WZB-Papers schicken

Sie bitte unbedingt einen an Sie adressierten Auf-

kleber mit sowie je paper eine Briefmarke im Wert

von 0,51 Euro oder einen "Coupon Reponse Inter-

national " (für Besteller aus dem Ausland)
Please send a self addressed label and postage stamps in the amount of 0.51 Euro or a "CouponReponse International" (if you are ordering from outside Germany) for each WZB-paper requested

\section{Absender / Return Address:}

Wissenschaftszentrum Berlin

für Sozialforschung

Presse- und Informationsreferat

Reichpietschufer 50

D-10785 Berlin-Tiergarten

Hiermit bestelle ich folgende(s) Discussion paper(s):

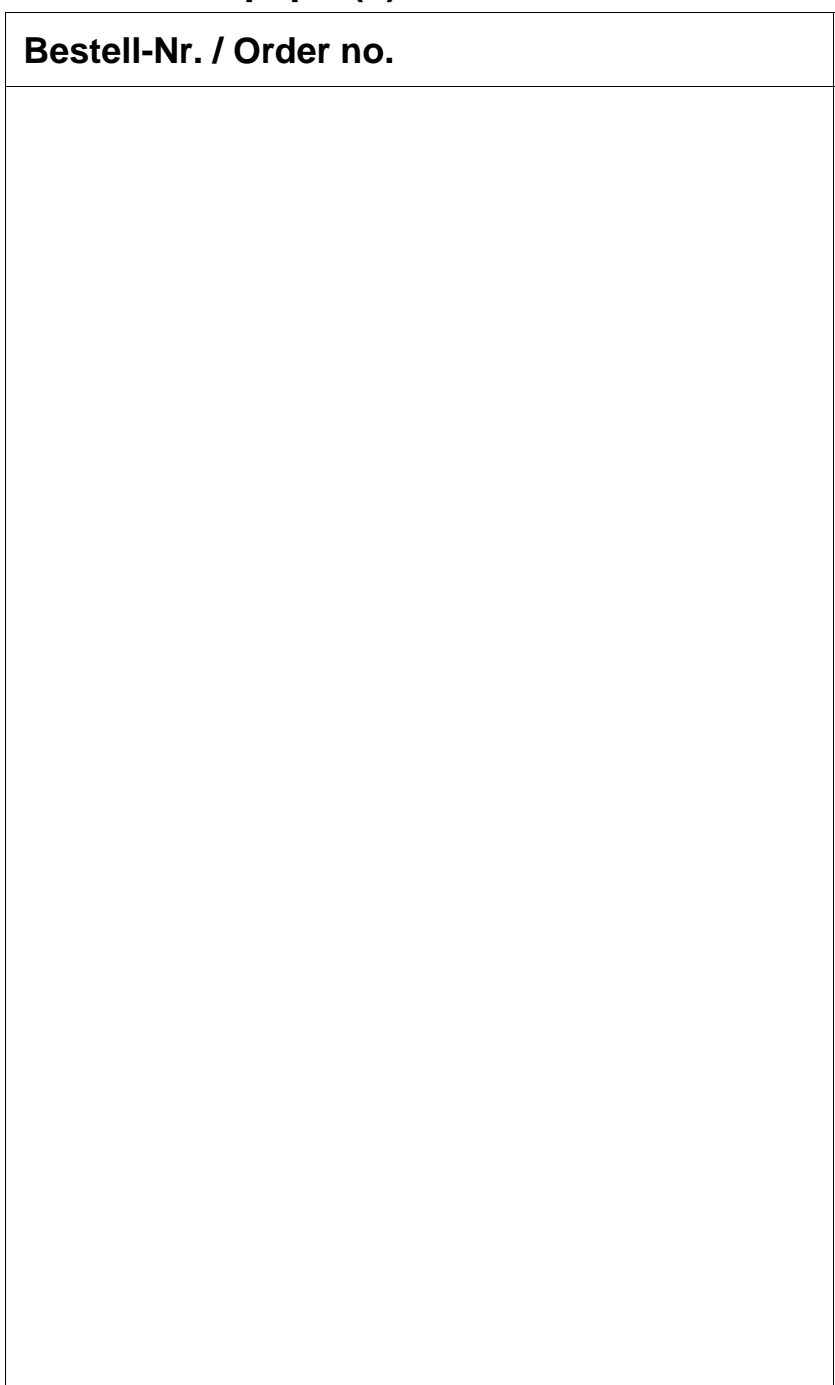

Please send me the following Discussion paper(s):

\section{Autor/in, Kurztitel /Author(s) / Title(s) in brief}

